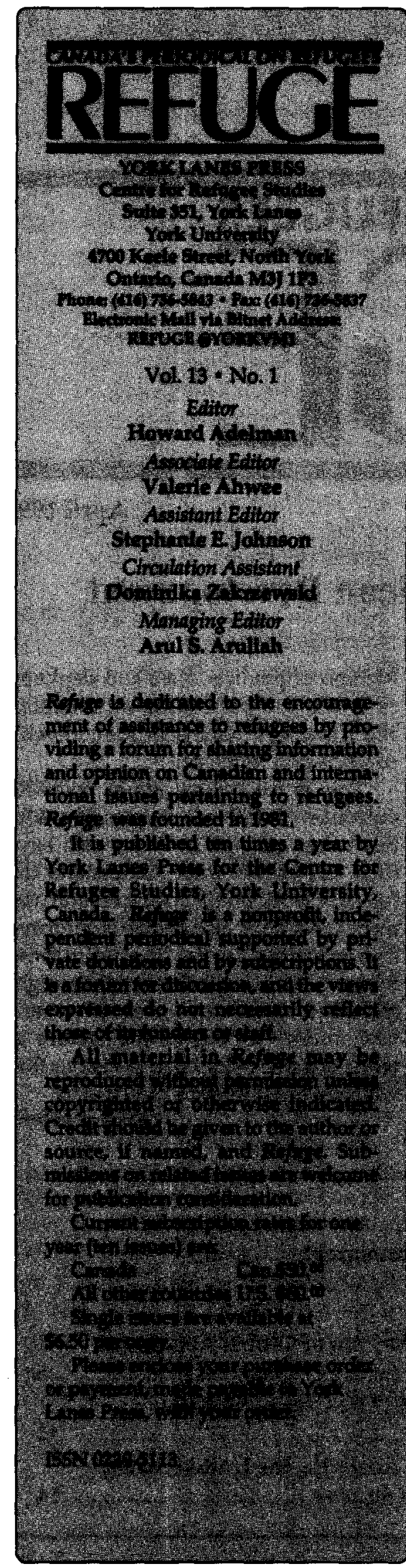

\title{
Canada's Response to Black African Immigrants
}

\author{
Yohannes Gebresellasie
}

Black Africans are nontraditional immigrants in Canada. Canada's traditional immigrants were from Europe and the United States. Prior to 1900 there were two major migrations of persons of African descent, who left the United States for Canada. "After the American War of independence, many United Empire Loyalists came to Canada with their slaves." ${ }^{1}$ Also, approximately 3,000 blacks who had fought for the British settled in Nova Scotia. In 1833, the government of Upper Canada passed an act that gave some rights to blacks. The act stated that "Negro slaves from the United States (in Canada) will not be extradited except for crimes of murder, larceny, or similar crimes of violence." 2 As a result, about 40,000 to 50,000 blacks found sanctuary in Canada. After 1900, however, Canadian policy strongly discouraged nonwhite immigration. Even as late as 1950 blacks were "inadmissible unless they fell in the preferred classes or were the spouses or minor children of Canadian residents." ${ }^{3}$ When Canada abandoned its discriminatory immigration policy in 1967, black African migrants, particularly those with higher education and professional skills, were able to enterCanada aslong as they could compete along the same standards with European or American immigrants.

Until then most immigrants who managed to enter Canada were of European descent, many of them from Great Britain. The records of de facto refugees who entered Canada from 1947 to 1967 list none of African origin, although some may have been included under the category of "Others." From 1968 to 1973, 207 African refugees came from the following countries: Egypt (8), Libya (3), Malawi (6), South Africa (3), Tanzania

Yohannes Gebresellasie, who is from Laval University, is currently a research exchange scholar at CRS.
(18) and Uganda (169). In 1972 Canada accepted some 6,000 Ugandan Asians. According to Dirks (1977, 244), those Ugandan refugees

\begin{abstract}
spoke English, possessed above average education and were considered to be self-reliant. In addition the majority of those applying to enter Canada easily qualified for admission under normal immigration regulations. These people, therefore, were the type Canada's immigration policy sought to attract. The only procedures and service programs which distinguished the Ugandan Asian movement from normal immigration patterns consisted of the dispatching of an immigration team to Kampala where no officials were normally posted, and the transporting of refugees to Canada initially was at government expense. Once in Canada, the refugees found themselves treated for the most part like any other immigrant with respect to government services.
\end{abstract}

During the 1970s immigration from Africa to Canada more than doubled compared to the 1950s and 1960s (see Table 1).

Northern African countries have been major sources of immigrants to Canada during the 1960s. Those countries encouraged emigration for people whose skills were not essential; this was considered one solution to domesticeconomic problems. In the 1970s more and more immigrants came to Canada from eastern African countries to escape political conflicts in the Horn of Africa. For example, Idi Amin's dictatorship in Uganda led to the expulsion of Ugandans, and conflicts in Ethiopia, Somalia, Eritrea and Tigray caused thousands to leave their countries to seek safety elsewhere.

During the 1980 s and 1990 s, socioeconomic and political conditions in Africa have increased the number of refugees from one million in 1970 to the 
current figure of approximately five million. This represents 1 percent of the total African population. The majority of African refugees are from the Horn of Africa. Refugees from this region are the second largest concentration of refugees anywhere, exceeded only by the estimated five to six million Afghan refugees who fled from the civil war in their country to camps in Pakistan and Iran.

\section{Canada's Response to African Refugees}

From the earliest days of the United Nations, Canada has played an important role in promoting peace and stability around the world and helped to create various humanitarian organizations, such as the United Nations Relief and Rehabilitation Administration, in order to help countries resolve their problems with displaced persons. Canada gave landed immigrant status to more than 160,000 eastern European refugees in the postwar years and encouraged the international community to work together to resolve the refugee crisis. Generally, the Canadian government has followed a liberal internationalist approach with regard to migration that reflects a humanitarian perspective to the problem of refugees and displaced people within the constraints of its domestic socioeconomic and political objectives.

The 1976 Immigration Act recognizes Canada's international obligation to refugees, the displaced and the persecuted. In that regard, Canada has welcomed significant numbers of displaced people from all over the world. When Canada introduced the refugee class in 1976, Africans refugees were mainly from Ethiopia, Somalia, Sudan, Djibouti and Uganda. An analysis of the Immigration and Refugee Board statistics for the year 1991, shown in Tables 3, 4 and 5, indicates that there were claims from virtually every country in Africa and those fleeing persecution have been generally given protection.

Canada has made financial contributions to help solve the African refugee crisis within the continent of Africa as opposed to resettling them in Canada. Canada's contributions to UNHCR (approximately \$3-4 million annually) are provided by the Canadian International Development Agency (CIDA); however, policy decisions are made by the Office of External Affairs in conjunction with CIDA and Canada Employment and Immigration.

The overall Canadian contribution to Africa is minimal compared to Canadian investments in South Africa. Some humanitarian organizations, such as Christian Aid, argue that industrialized countries, including Canada, should be more responsible in seeking solutions to refugee problems. One solution is increasing financial aid to international and nongovernmental agencies and the other is accepting more refugees from Third World countries.

\begin{tabular}{|c|c|c|c|c|c|}
\hline \multicolumn{2}{|c|}{$\begin{array}{c}\text { Table } 1 \\
\text { African Migration to Canada } \\
(1950-79)\end{array}$} & \multicolumn{4}{|c|}{$\begin{array}{c}\text { Table 2: } \\
\text { African Immigration Compared to } \\
\text { Total Annual Immigration to Canada }\end{array}$} \\
\hline Year & Volume & Year & Total & African & $\%$ \\
\hline 1950 & 213 & 1966 & 194,747 & 3,924 & 2.0 \\
\hline 1951 & 313 & 1967 & 222,876 & 4,596 & 2.1 \\
\hline 1952 & 698 & 1968 & 183,974 & 5,205 & 2.8 \\
\hline $\begin{array}{l}1953 \\
1954\end{array}$ & $\begin{array}{l}902 \\
755\end{array}$ & 1969 & 161,531 & 3,347 & 2.1 \\
\hline 1955 & 548 & 1970 & 147,713 & 2,858 & 1.9 \\
\hline 1956 & 1,079 & 1971 & 121,900 & 2,816 & 2.3 \\
\hline 1957 & 2,970 & 1972 & 122,006 & 8,428 & 6.9 \\
\hline 1958 & 1,355 & 1973 & 184,100 & 8,360 & 4.5 \\
\hline 1959 & 843 & 1974 & 218,465 & 10,381 & 4.8 \\
\hline $\begin{array}{l}1960 \\
1961\end{array}$ & $\begin{array}{r}833 \\
1.088\end{array}$ & 1975 & 187,881 & 9,950 & 5.3 \\
\hline $\begin{array}{l}1961 \\
1962\end{array}$ & $\begin{array}{l}1,088 \\
2,171\end{array}$ & 1976 & 149,429 & 7,631 & 5.1 \\
\hline 1963 & 2,431 & 1977 & 114,914 & 6,322 & 5.5 \\
\hline 1964 & 3,874 & 1978 & 86,313 & 4,270 & 4.9 \\
\hline 1965 & 3,196 & 1979 & 112,096 & 3,959 & 3.5 \\
\hline 1966 & 3,661 & 1980 & 143,366 & 4,332 & 3.0 \\
\hline 1967 & 4,608 & 1981 & 128,741 & 4,891 & 3.8 \\
\hline 1968 & 5,204 & 1982 & 121,268 & 4,516 & 3.7 \\
\hline $\begin{array}{l}1969 \\
1970\end{array}$ & $\begin{array}{l}3,297 \\
2,863\end{array}$ & 1983 & 89,323 & 3,669 & 4.1 \\
\hline 1971 & 2,841 & 1984 & 88,515 & 3,584 & 4.0 \\
\hline 1972 & 8,308 & 1985 & 84,640 & 3,581 & 4.2 \\
\hline 1973 & 8,307 & 1986 & 99,788 & 4,822 & 4.8 \\
\hline 1974 & 10,450 & 1987 & 153,078 & 8,600 & 5.6 \\
\hline 1975 & 9,867 & 1988 & 162,266 & 9,424 & 5.8 \\
\hline 1976 & $\begin{array}{l}7,752 \\
6372\end{array}$ & 1989 & 192,088 & 12,214 & 6.4 \\
\hline $\begin{array}{l}1977 \\
1978\end{array}$ & $\begin{array}{l}6,372 \\
4,261\end{array}$ & 1990 & 212,975 & 13,426 & 6.3 \\
\hline 1979 & 3,958 & Total & $3,683,993$ & 155,106 & 4.2 \\
\hline Total & 105,018 & \multirow{2}{*}{\multicolumn{4}{|c|}{ Source: Statistics Canada, 1990.}} \\
\hline $\begin{array}{l}\text { Source: Employ } \\
\text { Canada, Imm }\end{array}$ & $\begin{array}{l}\text { and Immigration } \\
n \text { Statistics, } 1980 .\end{array}$ & & & & \\
\hline
\end{tabular}




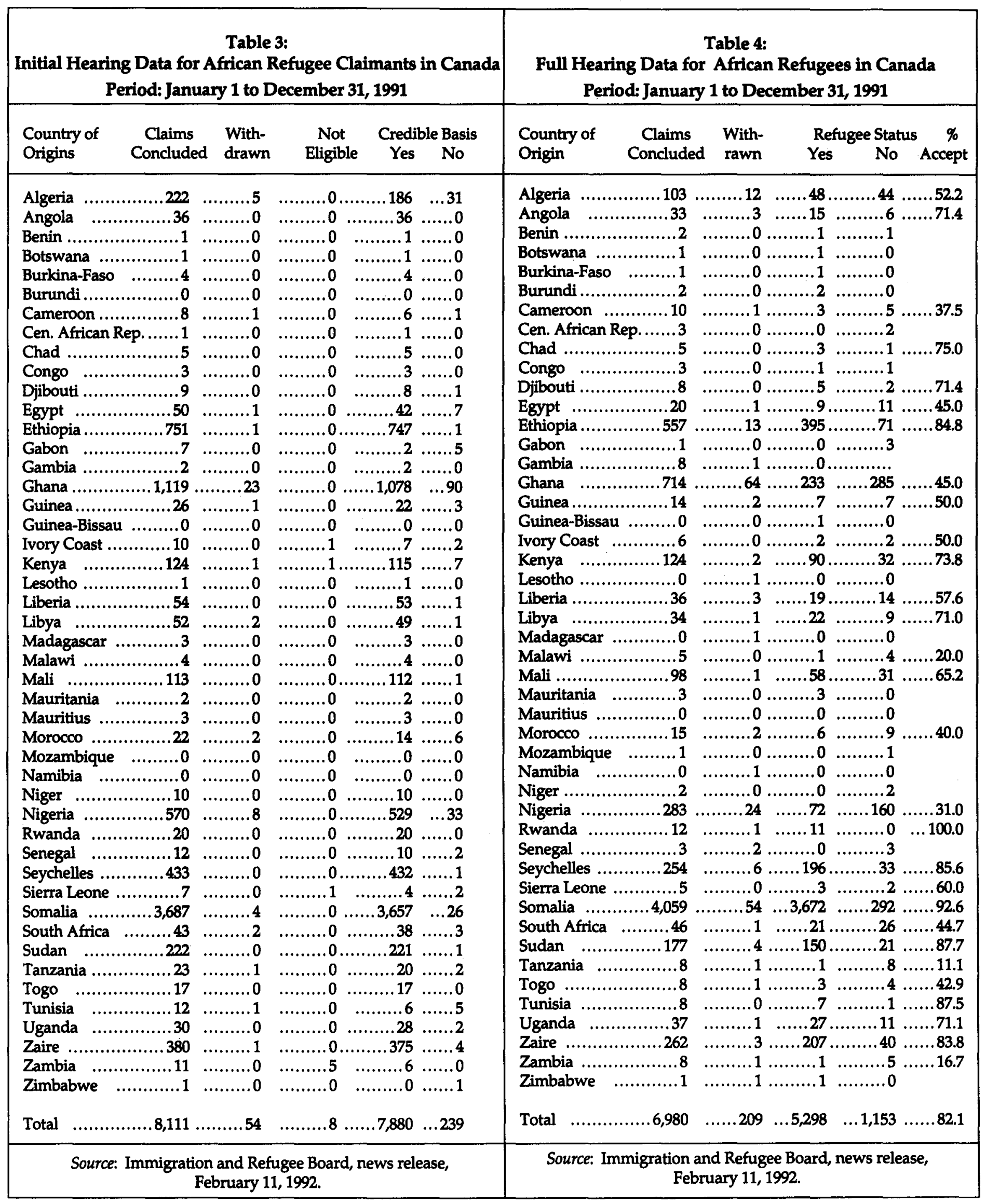


Table 5:

Refugee Claim Data for Major Refugee Source Countries from Africa (January 1 to December 31, 1991)

\begin{tabular}{llcrrrc} 
& Country & Claims & With- & \multicolumn{3}{c}{ Convention Refugee Status } \\
of Origin & Concluded & drawn & Yes & No & $\%$ Accepted \\
1. & Somalia & 4,059 & 54 & 3,672 & 292 & 92.6 \\
2. & Ghana & 714 & 64 & 233 & 285 & 45.0 \\
3. & Ethiopia & 557 & 13 & 395 & 71 & 84.8 \\
4. & Nigeria & 283 & 24 & 72 & 160 & 31.0 \\
5. & Zaire & 262 & 3 & 207 & 40 & 83.8 \\
6. & Seychelles & 254 & 6 & 196 & 33 & 85.6 \\
7. & Sudan & 177 & 4 & 150 & 21 & 87.7 \\
8. & Kenya & 124 & 2 & 90 & 32 & 73.8 \\
9. & Algeria & 103 & 12 & 48 & 44 & 52.2 \\
10. & Mali & 98 & 1 & 58 & 31 & 65.2 \\
& Top-10 total & 6,631 & 183 & 5,121 & 1,009 & 83.5 \\
& Others & 349 & 26 & 177 & 144 & 55.1 \\
& Total & 6,980 & 209 & 5,298 & 1,153 & 82.1 \\
& Source: Immigration and Refugee Board, news release, Feb. 11, 1992.
\end{tabular}

\section{Conclusion}

Canada's immigration policy with regard to blacks in general and black Africans in particular is a recent development. Growing numbers of refugees were accepted for humanitarian reasons, which increased the number of nontraditional immigrants or refugees in Canada. At present, Canada is facing one of its greatest challenges in terms of refugee claimants from Third World countries. Is Canada doing its part in sharing the refugee burden? Is its policy just or discriminatory towards certain groups?

Canadian immigration policy did not encourage resettlement of Africans. The entry of Africans to Canada has always been restrictive, even after the "White Canada Policy" was abolished. The African immigration to Canada averaged only about four percent of the total immigration to Canada.

Canada's financial assistance has been channelled either directly to host governments or to UNHCR or other international governmental and humanitarian agencies. Canada has supported a number of UNHCR's policy issues with regard to Africa, which included encouraging voluntary repatriation, resolving conflicts, assisting countries in reintegrating refugees and collaborating with organizations such as the Organization of African Unity. As a member of the international community and a defender of human rights, Canada has a responsibility in helping to resolve the displacement of migrants or refugees and fulfilling its international obligation in humanitarian aid. It is also to Canada's advantage to see peace and stability maintained in Third World countries because they may become Canada's major trading partners in the future.

\section{Notes}

1. Gerald Dirks, Canada's Refugee Policy: Indifference Or Opportunism (Montreal, Quebec: McGill-Queen's University Press, 1977), 22.

2. Ibid., 23.

3. Rhoda Howard, "The Canadian Government's Response to the African Refugee Problem," Journal of African Studies 15, no. 1 (1981): 103.

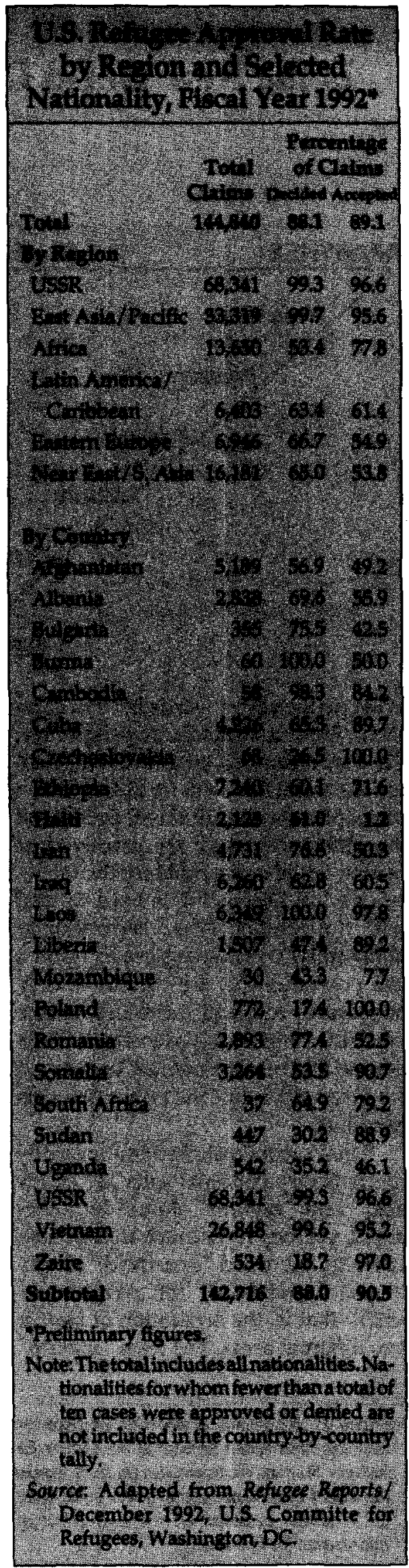

